\title{
The Transformation to an Online Course in Higher Education Results in Better Student Academic Performance
}

\section{(La transformación a la virtualidad de un curso en educación superior mejora el desempeño académico estudiantil)}

Teresa Freire

Carolina Rodríguez

Universidad de la República (Uruguay)

DOI: https://doi.org/10.5944/ried.25.1.31465

How to reference this article:

Freire, T., \& Rodríguez, C. (2022). The Transformation to an Online Course in Higher Education Results in Better Student Academic Performance. RIED. Revista Iberoamericana de Educación a Distancia, 25(1), pp. 299-322. https:// doi.org/10.5944/ried.25.1.31465

\begin{abstract}
Pandemic-forced remote teaching has highlighted the relevance of redesigning planification in order to transform face-to-face into online courses in higher education. Indeed, the type of e-learning activities, e-assessment and development of student-centred active learning tasks remains a challenge. In this work we investigated the academic performance of an online learning environment in a course with high number of enrolled students carried out in the pandemic context in 2020 and compared it to the 2019 face-to-face version of the course. The e-learning version of the course included some changes regarding the face-to-face to allow active student learning, digital learning environment, knowledge enforcement, and further exploitation of the available activities in the Moodle platform as for the face-to-face course, although the syllabus remained unchanged. This study finds both synchronous and asynchronous problem-solving based e-learning together with self-assessment and teambased continuous and individual questionnaire assessments to be valuable instructional methods that allowed higher student academic performance in comparison to the face-toface academic student results. Furthermore, the academic performance was directly related to the student participation in both team-based and individual activities during the course, demonstrating that the adaptation of the face-to-face course to the e-learning environment was, at least, as efficient as the traditional course, despite student resistance to e-learning and e-assessment.
\end{abstract}


Keywords: e-learning; digital learning environment; student academic performance; higher education.

\section{Resumen}

La enseñanza remota en línea forzada por la pandemia ha puesto en evidencia la necesidad de rediseñar la planificación de los cursos presenciales a su versión en línea de manera adecuada en la educación superior. De hecho, el tipo de actividades y evaluaciones en línea (digitales), sigue siendo un desafío en la educación universitaria. En este trabajo, investigamos la eficiencia de la transformación de un curso universitario de alta matrícula estudiantil presencial a modo en línea a través del estudio del desempeño académico estudiantil. La versión en línea del curso fue llevada a cabo durante el segundo semestre del año 2020 a través de la creación de un espacio de aprendizaje virtual y comparando el desempeño académico de los estudiantes con el obtenido durante la versión presencial del año 2019, en función a su participación en las actividades de evaluación continua. Se favoreció el aprendizaje activo por parte del estudiante, generando un ambiente digital de aprendizaje amigable, favoreciendo las instancias de autoevaluación, y respetando el currículo del curso. Este estudio muestra que las actividades en línea, tanto de forma asincrónica como sincrónica, basadas en la resolución de problemas, en conjunto con actividades continuas evaluables grupales e individuales, resultaron estrategias educativas valiosas que permitieron una mejora en el rendimiento académico estudiantil, demostrando que la incorporación de actividades digitales adecuadas fue tan eficiente como el curso tradicional, a pesar de la alta resistencia estudiantil a la continuidad de la enseñanza en línea y a la evaluación digital.

Palabras clave: enseñanza en línea; desempeño académico; adaptación; presencialidad; educación superior.

Nowadays, Covid19 pandemic has forced higher education e-learning and teaching by both students and non-learning experienced teachers, respectively, in the entire world. In addition, the expanding use of new information and communication technologies (ICTs) has been significantly developed in higher education in the last decade. In the context of this forced remote teaching, the relevance of redesigning planification in order to transform face-to-face into online courses, including the type of learning activities and assessment, remains a challenge, especially in relatively small nations (Wang, 2009) such as Uruguay. Indeed, assessments with digital resources might be tenfold more complex than traditional face-to-face courses (Romero-Martín et al., 2017; Yilan \& Koruyan, 2020), both for teachers and students. Moreover, the way that the digital environment transforms sensitive processes such as ICT-mediated learning assessment and the assessment of online learning systems needs to be especially addressed (Oguguo et al., 2020; TorresMadroñero et al., 2020).

The minimum criteria or expectations that must be considered in higher education in order to transform face-to-face courses into online or e-learning 
environments include focusing on online capabilities developed by both students and teachers, considering the intentional integration of technology to support teaching and learning processes, and emphasizing active learning (learner-centred) and/or problem solving-based approaches (Barkley, 2010; Barkley et al., 2005; Ferrufino Olmos, 2021). Therefore, it is more than clear today that online course design goes further the transfer of content online or replicating face-to-face classroom sessions. Instead, it involves redesigning content for an online environment; rethinking course goals, assessments, and learning experiences; integrating technology intentionally; and putting online structure and support in place to promote self-directed learning. Furthermore, the emergency-driven compulsory remote teaching has imposed teachers to attend all these criteria from different points of view and make teaching strategies more flexible and diverse, while considering different student learning abilities in order to successfully incorporate e-learning in higher education courses.

In this context, it is worth noting the relevance of the renewed role of educational teachers as mediators of knowledge providing effective and comprehensible description of activities, support and feedback to students in the ICT-based selfregulated learning environment, as well as the need to move towards e-assessment as a guarantee of student academic performance and the evaluation of the quality of online learning. Furthermore, careful considerations must be taken into account as online alternatives to face-to-face assessment in order to ensure the quality of digital assessment and to favour student learning. These might include continuous evaluation, direct learning tracking, team-work, oral activities to favour communicational activities beyond knowledge acquisition, or individual questions to students (Alyoussef, 2021; Jeong, 2017; Vilchez-Sandoval et al., 2021; Wang, 2009; Yilan \& Koruyan, 2020).

Digital education platforms have been very much exploited during remote education forced by Covid19 pandemic. Indeed, recent studies have demonstrated that the total number of activities in 2020 was significantly increased compared to the same period in 2019 (https://moodle.com/covid19/; Lapevska et al., 2021). In Uruguay, the education at the University of the Republic (Universidad dela República, UdelaR) also witnessed dramatic changes in the use of Moodle during 2020. In order to motivate students through e-learning, we adapted a Haematology and Immunology university course located in the second semester 2020 of the Medical Doctor (MD) curriculum career and compared the student academic performance between the face-to-face course (carried out before pandemic) and the e-learning environment adapted course, carried out during remote teaching by UdelaR in 2020, while face-to-face courses were cancelled. In this context, we applied flipped learning-like activities and two complementary kinds of assessment activities to favour the e-learning environment via Moodle (Hossain Khan \& OiriddineAbdoub, 2021; Jeong, 2017; Mursyidah et al., 2021; Vilchez-Sandoval et al., 2021). This work provides evidence of the success of a carefully designed course adapted to an e-learning environment in Uruguay during pandemics-induced remote higher 
education and its contribution to the academic performance of students, paving the way to new e-learning approaches in our country.

\section{METHODOLOGY}

We present a retrospective analysis of two versions of the same course in higher education with the same syllabus: a face-to-face and an online course with an e-learning environment (e-learning). This course is located in the sixth semester of the career of MD in the School of Medicine at the University of the Republic (Facultad de Medicina, Universidad de la República), Uruguay. It is composed of three modules, lasting four weeks each. At the end of each module, a multiple-choice questionnaire of four distractors is available for student assessment. Oral teambased activities based on problem solving and case-based learning are also available during the course as continuous assessment. None of the activities is compulsory. However, in order to pass the course, and be able to take the exam, students must reach a minimum of $40 \%$ in the overall of available assessments. Those students who obtain more than $70 \%$ are exempt from the final exam. Those who obtain less than $40 \%$ must retake the course.

A thousand and two hundred and four (1204) students enrolled in the faceto-face course performed during 2019, while a thousand and three hundred and seventy-two (1372) students enrolled in the digital course performed during 2020 (Table 1). Average age of students was 20 years old. Data for this study were collected from the list of grades for each student of all certifying assessments during both 2019 (face-to-face) and 2020 (online) editions of the course. Both courses required at least 25 -hour dedication per week. It is worth noting that the majority of students (>90\%) performed only this course (meaning that they were fully available for this course, while they did not carry out any other course at the same time) according to the 2008 curriculum of the MD career developed by Facultad de Medicina, Universidad de la República.

\section{Description of the face-to-face course}

The 2019 version of the course was composed of every day master lecturers (from Mondays to Fridays) of an average of $1 \mathrm{~h} 30$ min each, followed by $2 \mathrm{~h}$ discussion classes based on problem- or case-solving tasks in teams (formative assessment). Face-to-face activities were performed in groups of around 35 students. Certifying (scoring) team-based tasks were also available as: i) Two seminars, including the acquisition of knowledge and analyses of a research article linked with one of the main topics of the week, and an oral presentation in teams followed by questioning by the teacher (Table 1); and ii) Three workshops where students had to present the solution to a clinical case or problem linked to the main topics of each course module by a team-based oral presentation. Furthermore, there was an experimental 
activity in the Immunology laboratory, where students performed an experiment in teams and an individual oral report on the obtained results and their interpretation or significance (Table 1). Teams were composed of up to six students. Students could score points from continuous oral individual and team-based activities independently of the number students chose to carry out (1 to 6).

\section{Table 1}

Differences and similarities between face-to-face and online courses

\begin{tabular}{|c|c|c|}
\hline $\begin{array}{c}\text { Characteristics of the } \\
\text { course }\end{array}$ & Face-to-face (2019) & Online (2020) \\
\hline Number of enrolled students & 1204 & 1372 \\
\hline Theoretical activities & $\begin{array}{l}\text { face-to-face master lecturers } \\
\text { ( } 1 \mathrm{~h} 30 \mathrm{~min}) \text { per day (from } \\
\text { Mondays to Fridays) }\end{array}$ & $\begin{array}{l}\text { from } 3 \text { to } 5 \text { of } 20 \text { min videos } \\
\text { on youtube prepared by } \\
\text { teachers (from Mondays to } \\
\text { Thursdays) }\end{array}$ \\
\hline $\begin{array}{l}\text { Problem-solving formative } \\
\text { (not certifying) activities }\end{array}$ & $2 \mathrm{~h}$ per day & $1 \mathrm{~h}$ per day \\
\hline $\begin{array}{l}\text { Certifying problem-solving } \\
\text { activities }\end{array}$ & $10 \mathrm{~h}$ during the whole course & $\begin{array}{l}1 \mathrm{~h} \text { per day (from Mondays to } \\
\text { Thursdays) }\end{array}$ \\
\hline $\begin{array}{l}\text { Certifying problem-solving } \\
\text { activities in teams }\end{array}$ & $\begin{array}{l}2 \text { seminars (research article) } \\
3 \text { workshops } \\
1 \text { laboratory }\end{array}$ & $\begin{array}{l}5 \text { seminars (research article) } \\
5 \text { workshops }\end{array}$ \\
\hline $\begin{array}{l}\text { Maximum of points (over } \\
\text { 100) reachable by team- } \\
\text { based activities }\end{array}$ & $\begin{array}{l}16 \text { (any activity scored, } \\
\text { independently of the number } \\
\text { of the activities performed by } \\
\text { students }\end{array}$ & $\begin{array}{l}25 \text { (at least students had to } \\
\text { perform } 80 \% \text { of activities to } \\
\text { be able to score) }\end{array}$ \\
\hline $\begin{array}{l}\text { Individual assessment } \\
\text { by questionnaires (four } \\
\text { distractors) }\end{array}$ & $\begin{array}{l}28 \text { multiple choice questions } \\
\text { in } 3 \text { face-to-face tests up to } \\
90 \mathrm{~min}\end{array}$ & $\begin{array}{l}25 \text { multiple choice questions } \\
\text { in } 3 \text { online tests up to } \\
40 \text { min distributed in } 5 \\
\text { unidirectional pages }\end{array}$ \\
\hline $\begin{array}{l}\text { Maximum of points (over } \\
\text { 100) reachable by individual } \\
\text { questionnaires }\end{array}$ & $\begin{array}{l}3 \text { face-to-face tests of } 28 \\
\text { points each: } 84 \text { points in } \\
\text { total }\end{array}$ & $\begin{array}{l}3 \text { online tests of } 25 \text { points } \\
\text { each: } 75 \text { points in total }\end{array}$ \\
\hline $\begin{array}{l}\text { Self-assessment } \\
\text { questionnaires }\end{array}$ & non available & $\begin{array}{l}\text { One questionnaire at the end } \\
\text { of each week in the same } \\
\text { conditions as individual } \\
\text { online tests with feedback. }\end{array}$ \\
\hline
\end{tabular}

\section{Description of the online course}

The 2020 version of the course contained both online synchronous and asynchronous-based activities with the objective to develop problem solving tasks 
both in teams and individually. Asynchronous activities involved the analysis, comprehension and integration of concepts developed in videos by teachers according to the course syllabus. Between three and five short videos of up to twenty minutes with major concepts were prioritized (Table 1). These asynchronous activities replaced the face-to-face master lectures. Team-based activities were presented as: i) Five seminars, when the task was to analyse, describe and present a research article, and ii) Five workshops, when the task was to resolve a question, problem or clinical case. In both team-based activities students had to apply previously acquired theoretical knowledge and develop or put into practice communication skills (Table 1). Teams were composed of up to six students and prepared the task before the synchronous meetings (in a flipped-learning-like lesson) with the teacher in groups of up to 35 students. These activities were similar to those performed during the face-to-face course, although the organization and number was different. Indeed, in order to ensure student presence and participation during the synchronous activities, students were capable of scoring as long as they performed $80 \%$ of the oral activities, meaning that they had to do at least 8 from the 10 oral activities proposed during the whole duration of the course. Otherwise, they could not score any points. No laboratory activities were performed (Table 1).

\section{Statistical analyses}

Results were analysed using GraphPad Prism software 6.0 (GraphPad Software, San Diego, CA) by one or two-way ANOVA or Student t test, as indicated in the legends to Figures. Results were considered to be significantly different when ${ }^{*} \mathrm{p}<$ $0.05,{ }^{* *} \mathrm{p}<0.01,{ }^{* * *} \mathrm{p}<0.001$ and ${ }^{* * * *} \mathrm{p}<0.0001$.

\section{RESULTS}

\section{General analyses of student academic performance}

First, we analysed the population of students both in the face-to-face and online course performed in 2019 and 2020, respectively. As shown in Figure 1A, in both versions of the course participated a similar ratio of female and male students. In particular, the participation of more than two-thirds of the students were females (Figure 1A). When analysed according to their academic performance, the results of the study indicated that $20 \%$ of the students failed while $45 \%$ passed the face-to face course. On the other hand, only $15 \%$ of the students failed the online course in an e-learning environment whereas $43 \%$ passed it. However, only $35 \%$ of students participating in the face-to-face course, while $42 \%$ of the students who participated in the online course with an e-learning environment, were exempt from the exam (Figure 1B and Table 2), indicating an increase in the academic performance of 
the students after carrying out the online course with respect with the face-to-face course. On the other hand, the overall qualifications obtained by the students who failed or passed the course, as well as those that were exempt from the exam, were not significantly different between the face-to-face and online versions of the courses (Figure 1C). Finally, only $37 \%$ of the students performed the team-based assessment tasks during the face-to-face course, while the student participation (90\%) in these activities was significantly increased in the online course (Table 2).

\section{Figure 1}

Analyses of student academic performance after the face-to-face and online versions of the course

\section{A Face-to-face}

Online
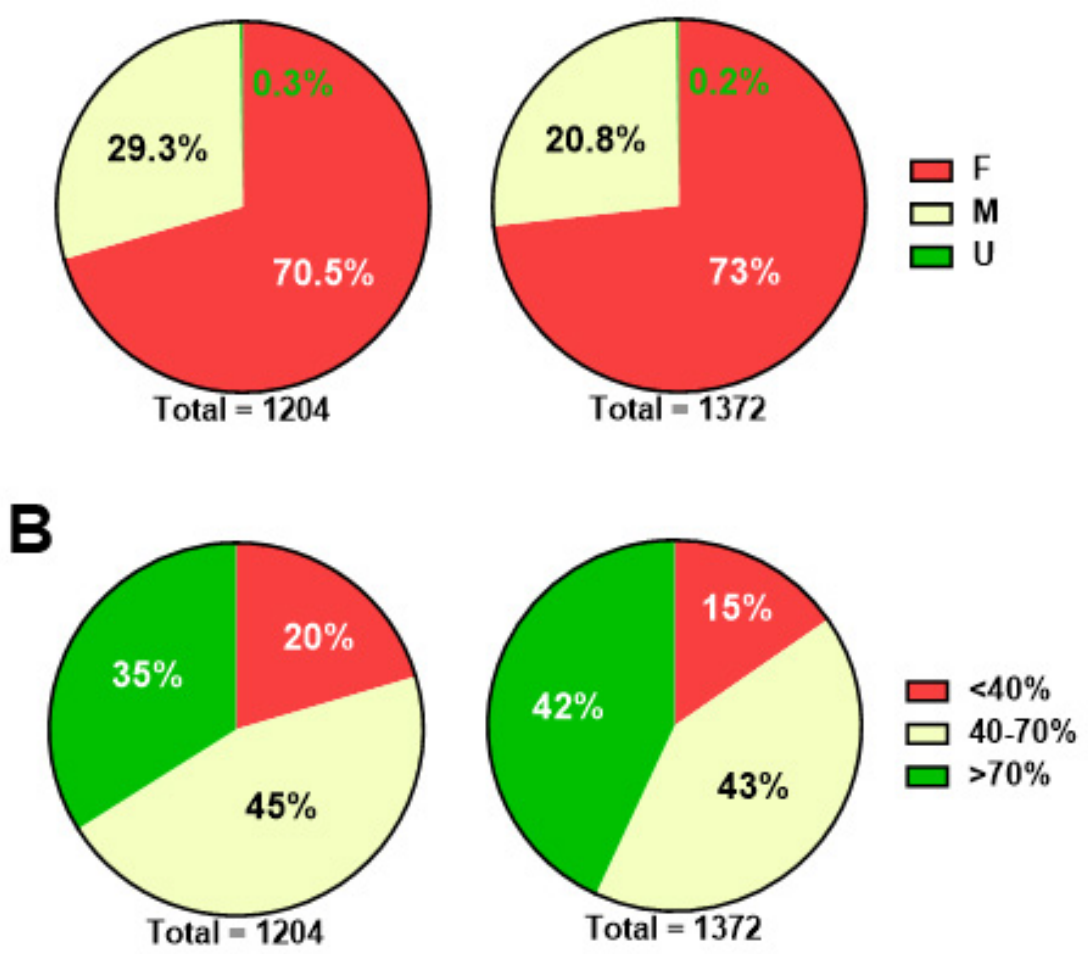


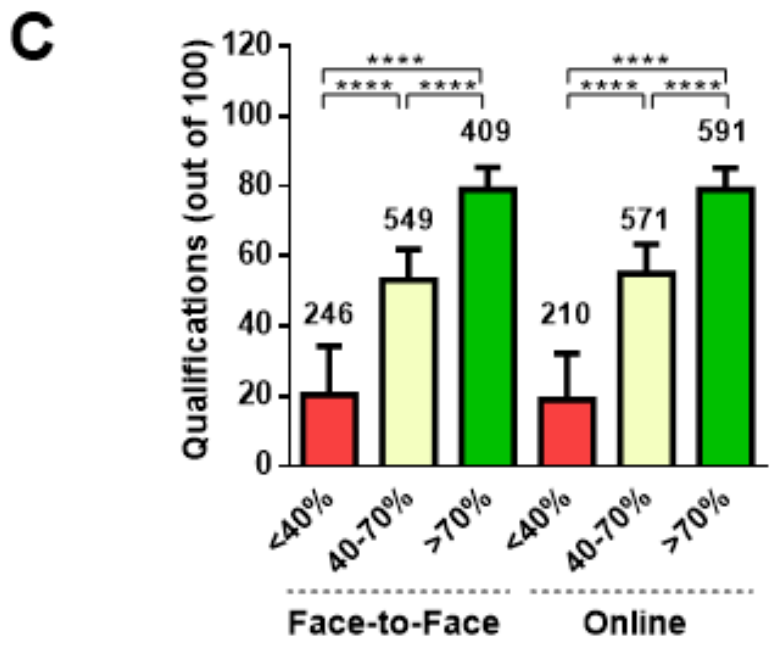

Note: A) Percentage of female (F, in red), male (M, in yellow) and gender undefined (U, in green) students who participated in the face-to-face (left) and online (right) courses. B) Percentage of students who failed (scored less than $40 \%$ of points), passed (scored between 40 and $70 \%$ of total points) and were exempt from the exam (scored more than $70 \%$ of total points) in the face-to-face (left) and online (right) courses. C) Student qualifications (in percentage) after carrying out the face-to-face (left) and online (right) courses. The number of students is shown above each bar. Statistical analyses were obtained by a two-way ANOVA test. Asterisks indicate statistically significant differences $(* * * 0<0.0001)$.

Table 2

Summary of academic performance of students in the two different course modalities

\begin{tabular}{|c|c|c|}
\hline Student academic performance & $\begin{array}{l}\text { Face-to-face } \\
(2019)\end{array}$ & Online (2020) \\
\hline Number of enrolled students & $1278(100 \%)$ & $1372(100 \%)$ \\
\hline $\begin{array}{l}\text { Number of students that did not pass the course } \\
\text { (must retake the course): } \\
<40 \% \text { points }\end{array}$ & $246(20 \%)$ & $210(15 \%)$ \\
\hline $\begin{array}{l}\text { Number of students that passed the course (able to } \\
\text { take the exam): } \\
\text { between } 40 \% \text { and } 69 \% \text { points }\end{array}$ & $549(45 \%)$ & $571(43 \%)$ \\
\hline $\begin{array}{l}\text { Number of students that were exempt from the exam: } \\
>70 \% \text { points }\end{array}$ & $409(35 \%)$ & $591(42 \%)$ \\
\hline $\begin{array}{l}\text { Number of students that performed at least } 80 \% \text { of } \\
\text { team-based assessment }\end{array}$ & $471(37 \%)$ & 1228 (90\%) \\
\hline
\end{tabular}


In order to deeply compare the academic performance of students who participated in the face-to-face and the online courses, we also analysed the percentage of students who failed or passed the course as well as those who were exempt from the exam according to student gender. As depicted in Figure 2, around two-thirds of the students who failed $(<40 \%$, part A) or passed the course $(40-70 \%$, part B), as well those that were exempt from the exam $(>70 \%$, part C) were female, considering both the participation in the face-to-face and online courses. Altogether, these results indicate that the same ratio of female, male and gender undefined students characterised the student population of both courses (Figure 1A), and that the academic performance did not depend on student gender in either of the course modalities.

\section{Figure 2}

Student academic performance in face-to-face and online courses according to gender

\section{Face-to-face Online}

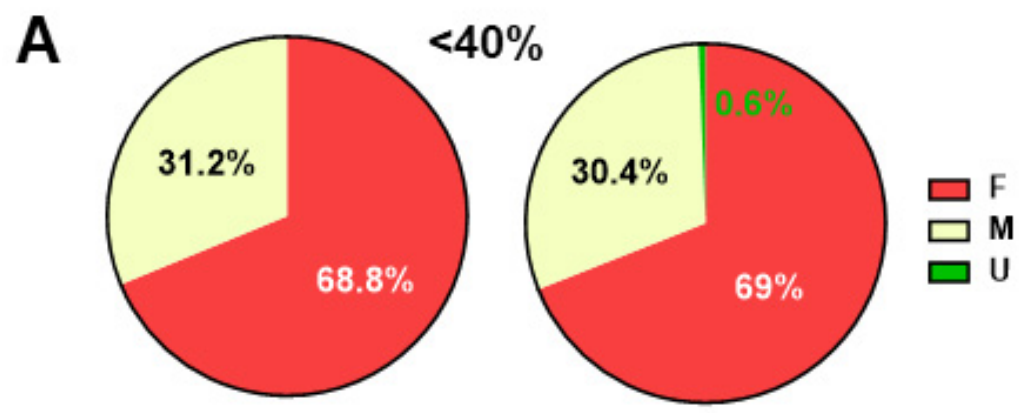




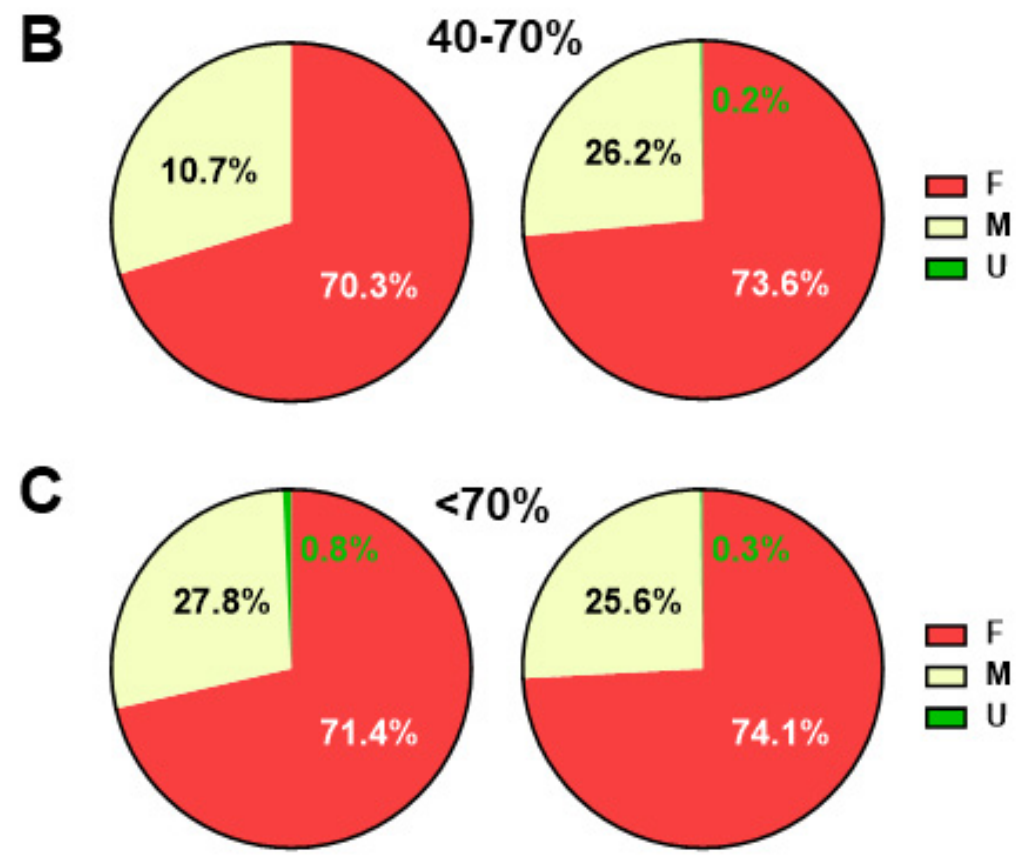

Note: A) Percentage of students who failed (scored less than $40 \%$ of points). B) Percentage of students who passed (scored between 40 and $70 \%$ of overall qualification points). C) Percentage of students who were exempt from the exam (scored more than $70 \%$ of overall qualification points). In all cases, student population who participated in the face-to-face course is shown on the left, while those who participated in the online course are on the right pie plots. Female (F), male (M) and gender undefined (U) students are indicated in red, yellow and green, respectively.

\section{Student academic performance according to their participation in oral team-based assessment tasks}

Most of students, about two-thirds, did not perform the continuous certifying assessment team-based activities during the face-to-face course (Figure 3A, left bar plot) while a four-fold increase in student participation ( $>80 \%$ ) was detected in the adapted e-learning environment (Figure 3A, right bar plot), likely as a result of the liability of carrying out at least $80 \%$ of these activities for students to be able to score points (Table 2). On the other hand, in both course modalities student grades significantly increased with the number of continuous team-based assessments (Figure $3 \mathrm{~B}$ ), demonstrating the impact of these activities in student academic performance, regardless of the course modality. 


\section{Figure 3}

Student academic performance in face-to-face and online courses according to the continuous team-based assessment activities

A

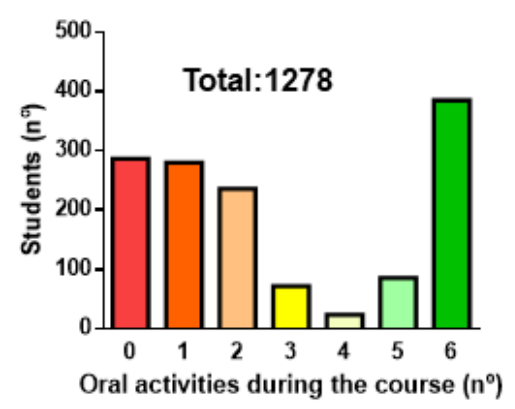

B

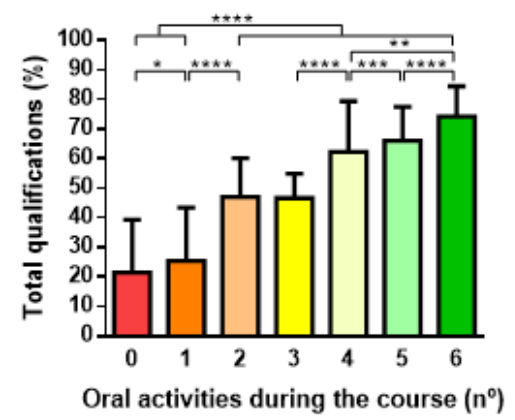

Online
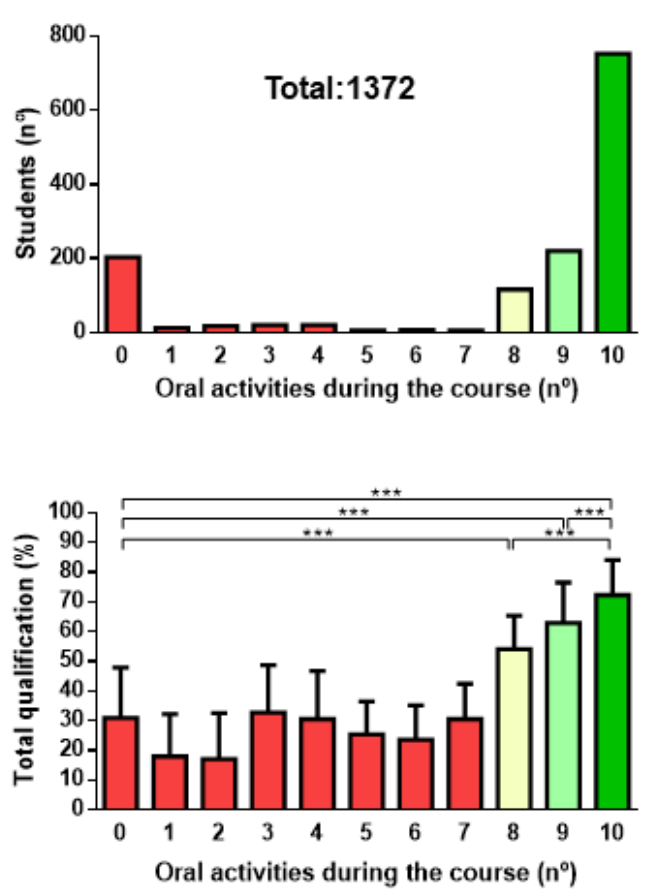

Note: A) Number of students according to their participation in 1, 2, 3, 4, 5 or 6 from the six available activities in the face-to-face courses, or 1, 2, 3, 4, 5, 6, 7, 8, 9, 10 from the 10 available activities in the online course. "o" indicates the number of students who did not participate in any of these activities. B) Overall student qualifications (\%) after carrying out the face-toface or virtual course according to their participation in continuous team-based assessment activities. Statistical analyses were obtained by a two-way ANOVA test. Asterisks indicate statistically significant differences $\left({ }^{*} \mathrm{p}<0.05,{ }^{* *} \mathrm{p}<0.01,{ }^{* *} \mathrm{p}<0.001\right.$ and $\left.{ }^{* * * *} \mathrm{p}<0.0001\right)$.

Then, we analysed student academic performance in each continuous teambased or individual assessment activities according to their participation during the course. As expected, students' grades obtained from continuous oral team-based assessment tasks significantly increased with the number of these activities, both during the face-to-face and online courses (Figure 4A). Of note, during the online course, students who performed less than $70 \%$ of these activities were not able to 
score (Figure 4A, right bar plot). With regard to individual multiple-choice midterm questionnaires, we observed that the individual academic performance of students significantly increased when they performed a higher number of continuous teambased assessment activities (Figure 4B, C and D, for the first, second and third midterm tests, respectively). Last, overall student grades also significantly correlated with the number of activities (Figure 4E), highlighting the importance for students of keeping up the course and permanent studying while they perform both continuous team-based assessments and individual midterm tests.

\section{Figure 4}

Student academic performance in face-to-face and online course modalities in different assessment activities, according to their participation of team-based tasks
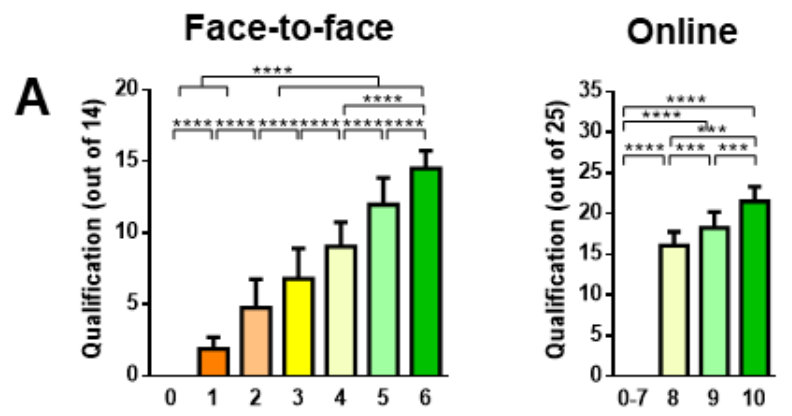

$$
\begin{aligned}
& \text { Oral team- } \\
& \text { based } \\
& \text { assessments }
\end{aligned}
$$
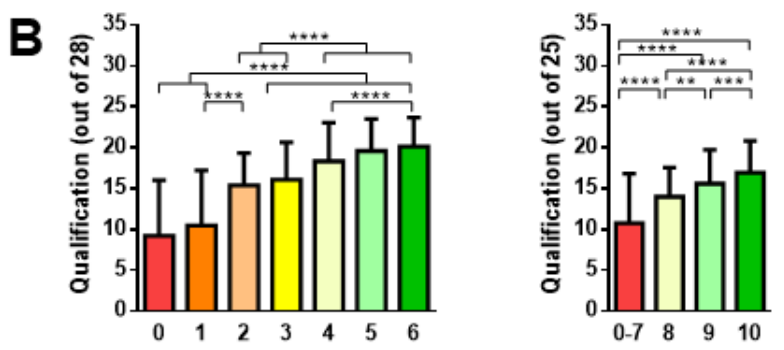

$1^{\text {st }}$ Multiple choice midterm individual

assessment
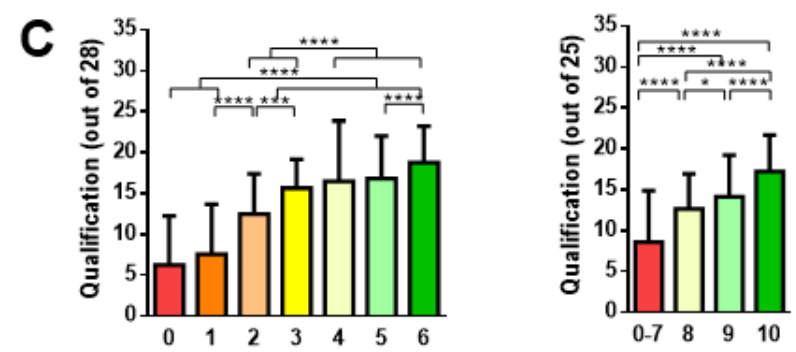

$2^{\text {nd }}$ Multiple choice midterm individual assessment 

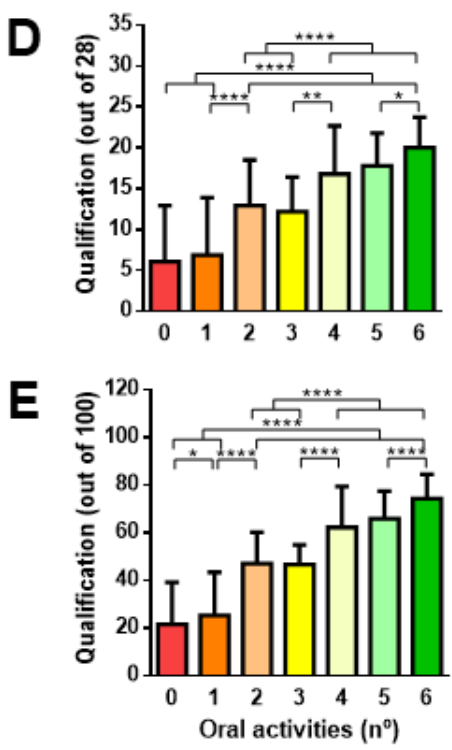

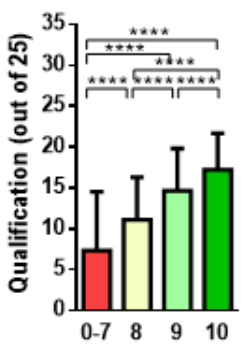

$3^{\text {rd }}$ Multiple

choice midterm

individual

assessment

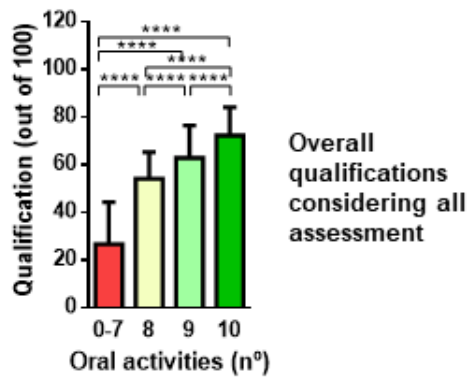

Note: A) Student qualifications in the team-based assessment activities during the face-toface (up to 14 points) and online (up to 25 points) courses according to their participation in continuous team-based assessment activities. B-D) Student qualifications in the individual first (B), second (C) and third (D) multiple-choice midterm questionnaires during the face-to-face (up to 28 points) or online (up to 25 points) course modalities according to their participation in continuous team-based assessment activities. E) Overall student qualifications (\%) after carrying out the face-to-face or virtual course according to their participation in continuous team-based assessment activities. Statistical analyses were obtained by a one-way ANOVA test. Asterisks indicate statistically significant differences $\left({ }^{*} \mathrm{p}<0.05,{ }^{* *} \mathrm{p}<0.01,{ }^{* * *} \mathrm{p}<0.001\right.$ and ${ }^{* * * *} \mathrm{p}<0.00001$

The results obtained from this study also showed that the vast majority of students who carried out all continuous team-based activities during the face-to-face course were exempt from the exam with respect to those that did not enrol in these activities (Figure 5A). However, the majority of students who did not participate in these activities was not exempt from the exam (Figure $5 \mathrm{~A}$ ). Moreover, most of the students who passed the face-to-face course, obtaining between 40 and $70 \%$ of total grades, participated in at least one of the team-based assessment activities (Figure $5 \mathrm{~A}$ and B). Finally, students who participated in all of the proposed continuous assessment activities did not fail the course (Figure $5 \mathrm{~B}$, right bar plot). 


\section{Figure 5}

Overall student academic performance after the face-to-face course according to their participation in the team-based assessment activities

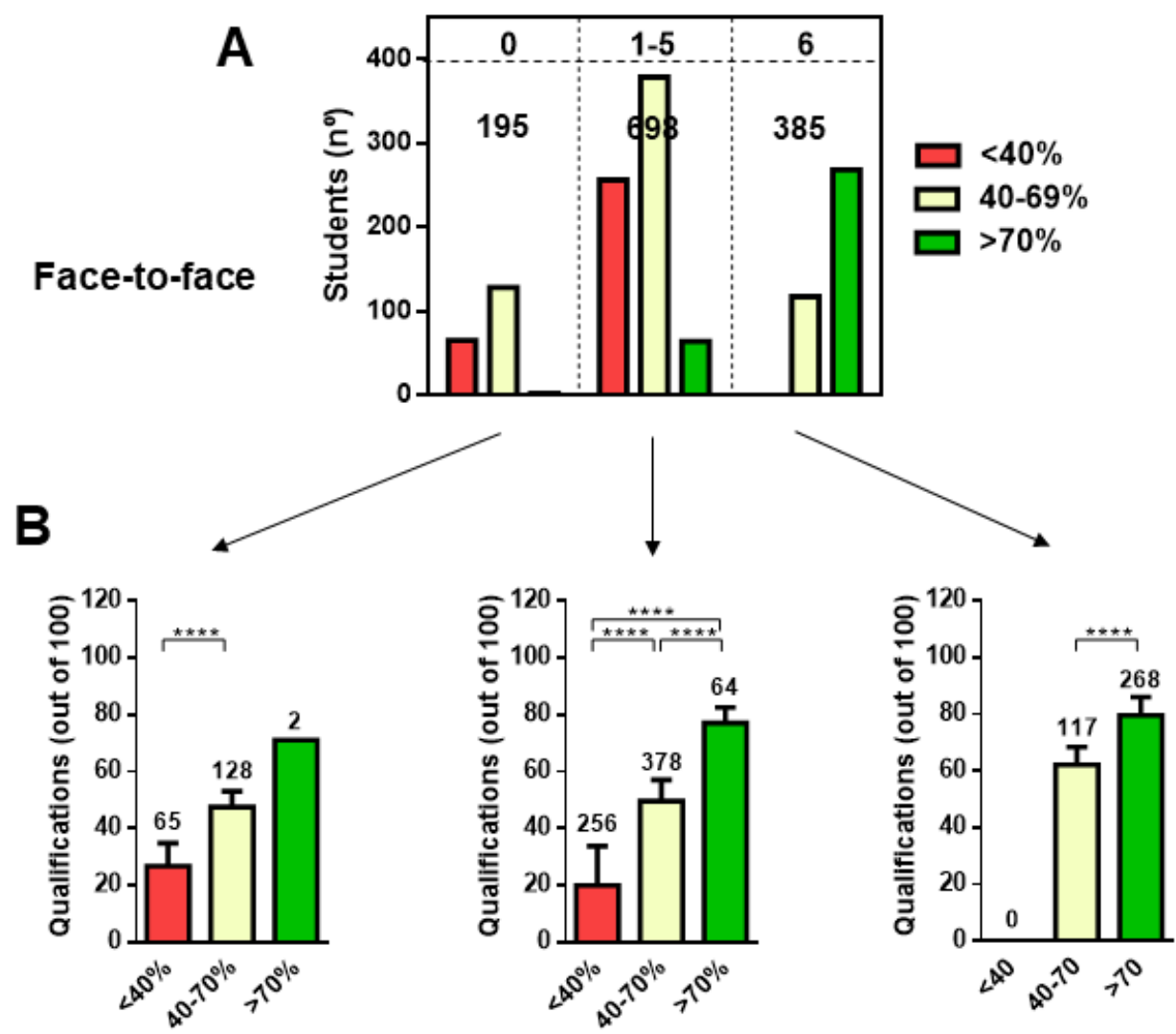

Note: A) Number of students who failed (scored less than $40 \%$ of points), passed (scored between 40 and $70 \%$ of total points) and were exempt from the exam (scored more than $70 \%$ of total points) according to their participation in none (o), one to five (1-5) or six (6) teambased activities. B) Percentage of student qualifications who failed (left bar plot), passed the course (centre bar plot) or were exempt from the exam (right bar plot) according to their participation in none (o), one to five (1-5) or six (6) team-based assessment tasks. The number of students is shown above each bar. Statistical analyses were obtained by a one-way ANOVA test. Asterisks indicate statistically significant differences $(* * * 0<0.0001)$.

On the other hand, both the number of students who passed the course and were exempt from the exam increased significantly when performing 8, 9 and 10 
team-based assessment tasks in the e-learning environment during the online course, whereas almost none of these students failed the course (Figure 6A and B). Furthermore, only one of those students who performed the 10 available team-based activities failed the course (Figure 6B, right bar plot).

\section{Figure 6}

Overall student academic performance after the online course according to their participation in the team-based assessment activities

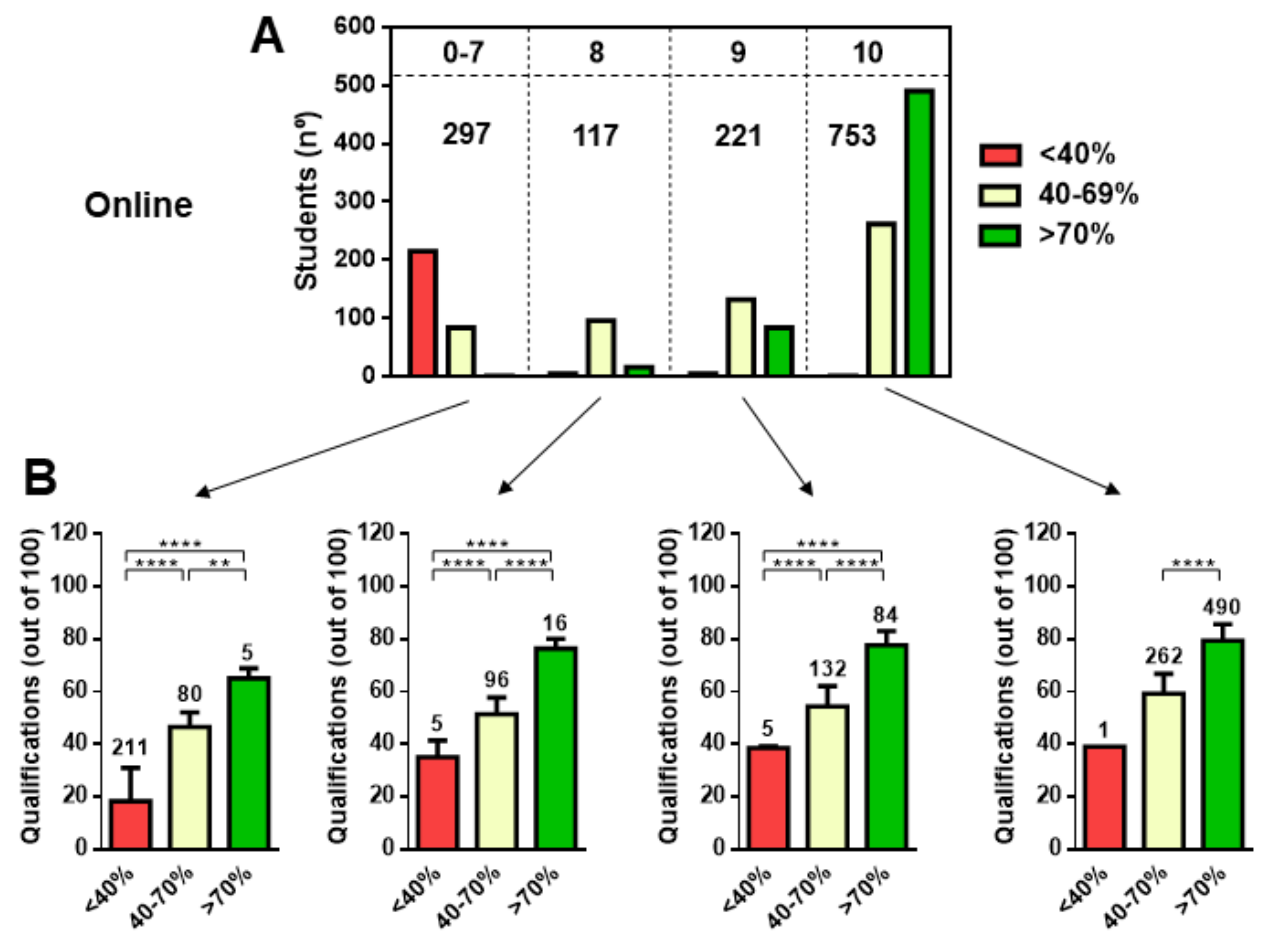

Note: A) Number of students who failed (scored less than $40 \%$ of points), passed (scored between 40 and $70 \%$ of total points) and were exempt from the exam (scored more than $70 \%$ of total points) according to their participation in less than 7 activities (o-7), eight (8), nine (9) or ten (10) team-based activities. B) Percentage of student qualifications of the students who failed (left bar plot), passed the course (centre bar plot) or were exempt from the exam (right bar plot) according to their participation in less than 7 activities (o-7), eighth (8), nine (9) or ten (10) team-based assessment tasks. The number of students is shown above each bar. Statistical analyses were obtained by a one-way ANOVA test. Asterisks indicate statistically significant differences $\left({ }^{* *} \mathrm{p}<0.01\right.$ and $\left.{ }^{* * * *} \mathrm{p}<0.0001\right)$. 


\section{Overall student academic performance during the course and in the final exam}

Interestingly, students who performed the team-based assessment activities available in the online course obtained significantly higher qualification scores than those who performed the face-to-face course (Figure $7 \mathrm{~A}$ ). In addition, this difference remained significant regardless of the student participation in teambased assessment activities (Figure $7 \mathrm{~B}$ ), demonstrating a better student academic performance during the online modality of the course.

\section{Figure 7}

Overall student qualifications after face-to-face and online modalities of the course
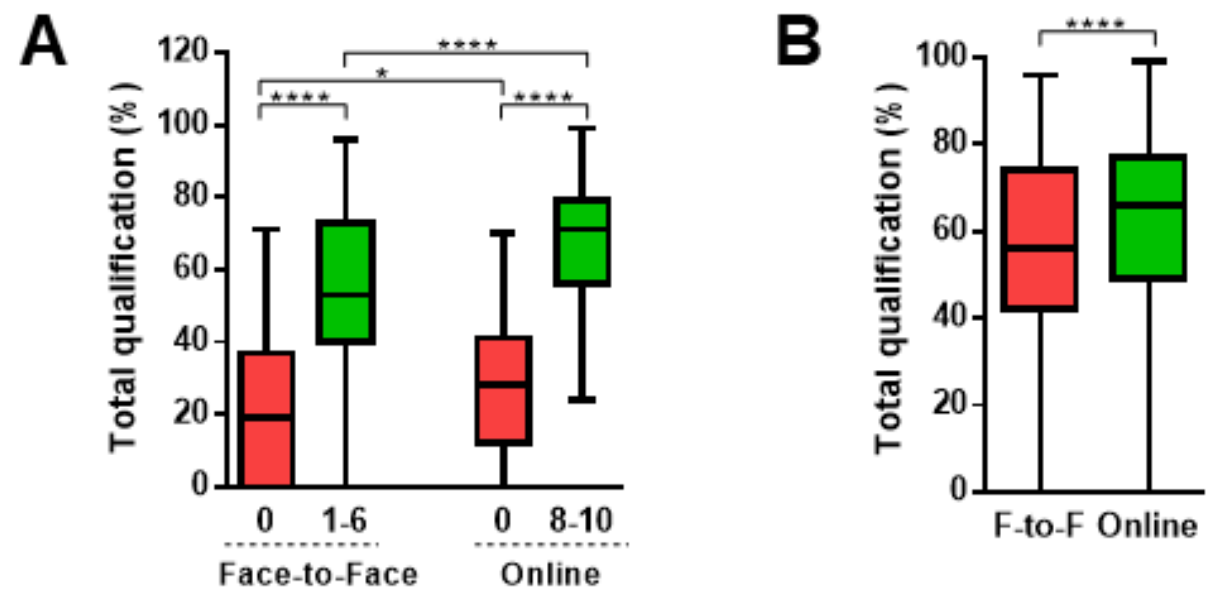

Note: A) Overall student qualifications (\%) after carrying out the face-to-face or online course according to their participation in team-based assessment activities. B) Overall student qualifications (\%) after carrying out the face-to-face or online course. Statistical analyses by a one-way ANOVA (A) or Student $t$ (B) tests. Asterisks indicate statistically significant differences $\left({ }^{* *} \mathrm{p}<0.01\right.$ and $\left.{ }^{* * * *} \mathrm{p}<0.0001\right)$.

Finally, one-fifth of the students who passed the face-to-face course and could take the final exam (individual multiple-choice face-to-face questionnaires) were able to approved it with a minimum required of $60 \%$ or correct responses (Figure $8 \mathrm{~A}$ ), while one-fourth of the students who passed the online course approved the final questionnaire in the Moodle platform (Figure 8B). Altogether, these analyses demonstrate that those students who performed the online course adapted to an 
e-learning environment had better academic performance both during the course and after (final exam) than those who enrolled in the face-to-face course.

\section{Figure 8}

Academic performance in the final exam of students who passed the face-to-face and online courses

\section{A Face-to-face B Online}
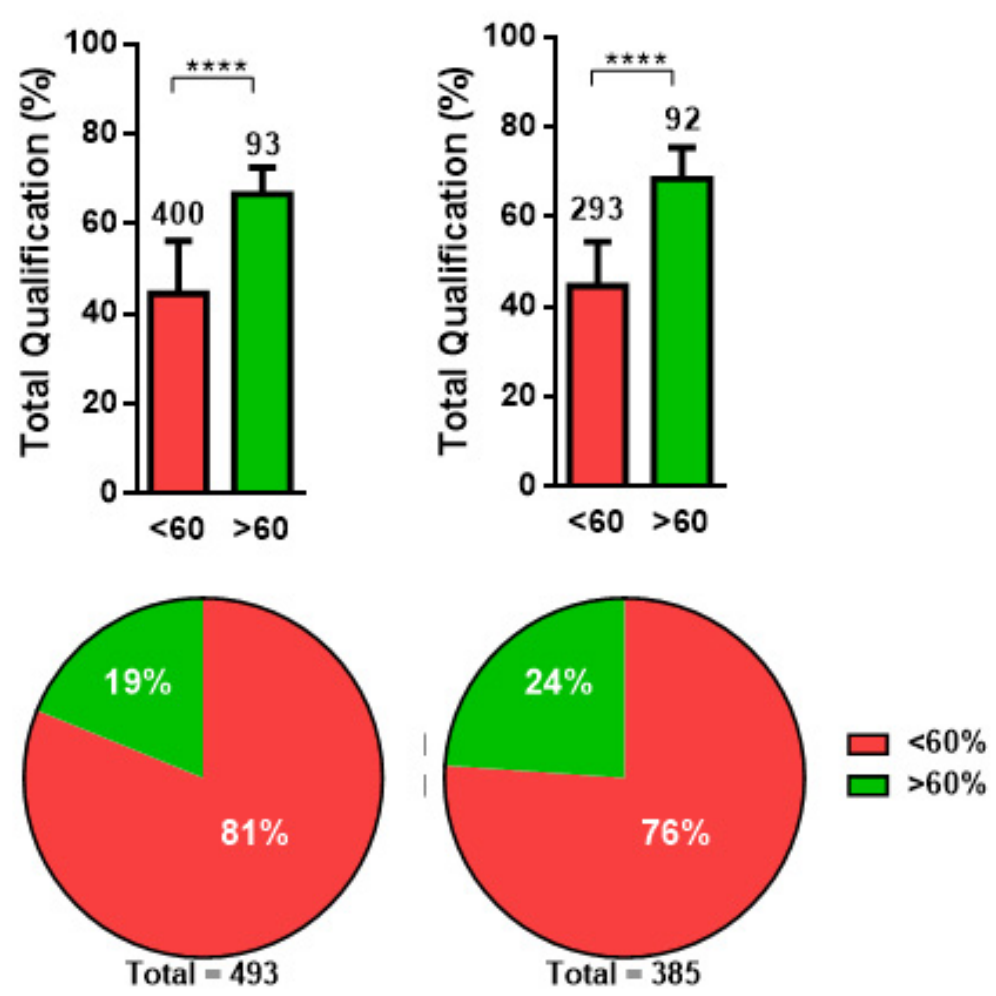

Note: A) Student qualifications (\%) in the final exam of those who passed the face-to-face course (upper bar plot) and percentage of students who failed (scored less than 60\%) or passed (scored more than 60\%) the exam after taking the face-to-face course (lower pie plot). B) Percentage of student qualifications in the final exam of those that passed the online course (upper bar plot) and percentage of students who failed (scored less than 60\%) or passed (scored more than 60\%) the exam after taking the online course (lower pie plot). Statistical analyses were obtained by a student $t$ test. Asterisks indicate statistically significant differences $(* * * \mathrm{p}<0.0001)$. 


\section{DISCUSSION}

Although the pandemic-induced emergency digital education is not the ideal situation to transform face-to-face learning into an online course with and adequate e-learning environment (Alyoussef, 2021; Murphy, 2020), it has significantly forced Uruguayan teachers to adapt their courses to the modern digital era. This context can be transformed into a huge opportunity for small countries such as Uruguay, and considered as a milestone in online higher education. For those teachers who had to adapt their courses immediately after universities lockdown, the transfer, but not the conception or creation of an online course, has been carried out. However, in our case, in which the course was performed between August and October 2020 (5 months after building institution lockdown and having started remote education), we were able to redesign the course, creating specific activities adapted to e-learning, incorporating complementary types of team-based and individual assessment online activities, and developing a new e-learning environment via educative online platforms, such as Moodle (EVA, Espacio Virtual de Aprendizaje) specifically adapted for e-learning and not used as a mere repository as it was the case during the face-to-face course in 2019. Importantly, the designing and development of the online version of our course has also been favoured by the development of an intensive online program for emergency teaching in higher education in the context of Covid19 pandemics in Uruguay, resulting in an enriching and rapid alternative to the transition to emergency remote education (Rodés et al., 2021). During this educative formation process that took place during 2020, an extensive analysis of teachers' contributions and interactions to assess appropriation of educational principles, methodologies and tools applied to online course redesign in the light of critical digital pedagogy were developed (Rodés et al., 2021), allowing teachers to acquire novel tools, that in our course were applied to the online design of the course by the coordinators. Furthermore, a great support by the institution (UdelaR) was available in order to guide the design of online courses during emergency teaching, undoubtedly favouring the design of more adequate online course and e-learning environment, as previously suggested (Martin et al., 2019). Thus, we were capable of incorporating a more reflecting and effective process and tools to apply in Uruguayan online higher education, which favoured a better student academic performance.

Therefore, the main questions that derive from our analyses are: How and why could students enrolled in the adapted online course have a better academic performance than those who performed the face-to-face course? First, it must be considered that academic performance is a consequence of complex and diverse processes, that depend on multiple factors, including cognitive, metacognitive, motivational and social characteristics of students (Baars \& Arnold, 2014; Esteban et al., 2017; Fonseca \& García, 2016). Second, it should also be taken into account that our course is characterised by a high student enrolment (between 1200 and 1400 students). In this context, the face-to-face course was composed, on the one hand, by 
master lectures in three different schedules (morning, afternoon, and evening). This forced around 400 students to group into a big classroom to attend to the face-toface master lectures, and to take notes and incorporate knowledge in a non-friendly environment, in which at least one third of the students had to sit on the floor and did not have access to the same (audio or visual) perception conditions of the lecture. Although teachers shared the different lecture presentation files in the face-to-face course, students were not able to "assist" to these lectures repetitive times and had to trust their notes. In the e-learning environment that we created in the online course, we transformed these 1 hour and 30-minute lectures into short videos available on the internet. Therefore, we suggest that these facts have led to: i) prioritize the content of each lecture by teachers, and ii) give students the possibility to watch and listen to the theoretical concepts presented in the videos repetitive times, with the available downloadable document presentation, improving student knowledge acquisition. Indeed, this has been one of the main advantages students found in our course, as they have stated in a specific interview to students at the end of the course. Interestingly, our conclusions are supported by those found after a study carried out by Queiroga and collaborators showing that the students who had more interactions and interventions in the e-learning environment of a course associated with better academic performance (Queiroga et al., 2021). Furthermore, they also described the fact that student academic performance also depended on the number of different courses the students took at the same time (Queiroga et al., 2021). Thus, it would be interesting to analyse these aspects in our study.

The second point to consider is the type of assessment activities. Although during the face-to-face course students had the opportunity to perform midterm individual multiple-choice tests at the end of each course module, they could score up to $84 \%$ of the available points, while when performing the team-based continuous assessment tasks they could score up to $16 \%$ of the points (Table 1). In the online course that we designed, the number of problem-solving team-based activities was increased, giving the students the opportunity to gather up to $25 \%$ of the points (Table 1). Furthermore, in order to force student participation in the synchronous encounters by the Zoom platform, students were required to participate at least in 8 out of the 10 available team-based certifying assessment tasks to be able to score, favouring or forcing active learning. This has, as shown by the results of this work, considerably increased the number of students that presented these activities, and therefore, the chance for students to score more points. Thus, it is likely that these conditions motivated student participation, resolving one of the main problems in e-learning: encouraging student participation, as has already been reported (Groves \& O'Donoghue, 2009). Nevertheless, the possibility that students only took part because of the extrinsic reward remains a possibility, in which case a "blended" approach, delivering a combination of online and traditional face-to-face activities is recommended. 
On the other hand, it is worth noting that better student academic performance was also found at the individual level through the multiple-choice tests available at the Moodle platform adapted by our University (UdelaR). Thus, apparently, by performing more team-based assessments in which students had to apply the knowledge gathered in the videos, ameliorated their academic performance individually too. In this context, it is important to highlight that ICTs constitute a valuable tool to enhance e-learning since they can foster student active learning by turning them into being creative, collaborative and responsible learners, not only at the individual level but also as a part of a team or community (Oguguo et al., 2020; Torres-Madroñero et al., 2020; Yilan \& Koruyan, 2020). Nevertheless, one of the main challenges for students in e-learning approaches is that they need autoregulation, organization and other metacognitive skills while instructors become mediators who guide students to apply knowledge, as they have stated while interviewed about this point. In addition, problem- or case-based learning in online courses need instructional design, facilitation, and technology support, being the latter one of the most important to foster student comprehension and e-learning (Oguguo et al., 2020; Torres-Madroñero et al., 2020; Yilan \& Koruyan, 2020).

Third, self-assessment activities were also available at the end of each week, that were set up in exactly the same conditions as the individual multiple-choice midterm tests, allowing students to practice and better prepare for this type of online assessment. In fact, this was one of the facts that students reinforced when giving their opinion on the usefulness of the self-assessment activities. Thus, the proposed mix of online assessment was apparently effective. However, it is worth noting that online assessment is a great challenge by itself and needs to articulate not only student comprehension based on the contents and types of proposed activities, but also the quality of the e-learning assessment (Bates, 2019). In the same line, the fact that the student generation that took the online course grew up in the internet age, might have also contributed to the student academic success since, as it has already been reported, today's digital ICTs are an important part of the student's life (Prensky, 2004).

Finally, we demonstrate in this work that students who passed the online course in 2020 also had a better academic performance during the individual multiplechoice final exam than those who passed the face-to-face course in 2019. This is of great importance if we consider that both exams (2019 and 2020) were carried out in exactly the same face-to-face conditions in December of each year, highlighting the relevance of the new e-learning activities incorporated in the online course performed during university lockdown and favouring active learning. 


\section{CONCLUSIONS}

This study investigated the efficiency of the transformation of this course from face-to-face to online both synchronous and asynchronous learning activities, through the analyses of student academic performance of an e-learning environment in a high student enrolment course in Haematology and Immunology at the School of Medicine carried out in the pandemic context in 2020 and compared it to the faceto-face version of the course performed in 2019. The online version of the course included some changes with respect to the face-to-face to favour active student learning, e-learning environment and knowledge enforcement, although the syllabus remained unchanged: a flipped learning approach, the increased use of team-based learning and development of communication skills, continuous assessment of oral activities together with individual-based questionnaires for academic assessment and self-assessment and further exploitation of the available activities in the Moodle platform with respect to the face-to-face course. This study found both synchronous and asynchronous problem-solving based e-learning together with self-assessment and team-based continuous and individual questionnaire assessments to be a valuable instructional method that allowed higher student academic performance, highlighting the positive impact of participating in team-based assessment tasks in both individual and team-based academic performance. It also suggests that the adaptation of the face-to-face course to the e-learning environment was, at least, as efficient as the traditional course, despite student resistance to e-learning and e-assessment.

\section{REFERENCES}

Alyoussef, I. (2021). E-Learning System Use During Emergency: An Empirical Study During the COVID-19 Pandemic. Frontiers in Education, 6, 1-11. https:// doi.org/10.3389/feduc.2021.677753

Baars, G. J. A., \& Arnold, I. J. M. (2014). Early Identification and Characterization of Students Who Drop Out in the First Year at University. Journal of College Student Retention: Research, Theory \& Practice, 16(1), 95-108. https://doi.org/10.2190/ CS.16.1.e

Barkley, E. (2010). Student Engagement Techniques: A Handbook for College Faculty. Editorial Bosse Bass.

Barkley, E., Cross, K. P., \& Major, C. H. (2005). Técnicas de aprendizaje colaborativo: Manual para el profesorado universitario. Ediciones Morata SRL.

Bates, A. W. (2019). Teaching in a Digital Age: Guidelines for designing teaching and learning. Second Edition, TONY BATES ASSOCIATES LTD.

Esteban, M., Bernardo, A., Tuero, E., Cervero, A., \& Casanova, J. (2017). Variables influyentes en progreso académico y permanencia en la universidad. European Journal of Education and Psychology, 1O(2), 75-81. https://doi.org/10.1016/j

Ferrufino Olmos, J. (2021). Estrategia didáctica aprendizaje basado en problemas aplciada a la enseñanza Aprendizaje de la Química Orgánica I. Documentación Digital de la Universidad 
Mayor de San Simón. http://hdl.handle. net/123456789/23711

Fonseca, G., \& García, F. (2016). Permanencia $\mathrm{y}$ abandono de estudios en estudiantes universitarios: un análisis desde la teoría organizacional. Revista de la Educación Superior, $X L V$ (179), 25-39. https://doi. org/10.1016/j.resu.2016.06.004

Groves, M., \& O’Donoghue, J. (2009). Reflections of Students in Their Use of Asynchronous Online Seminars. Educational Technology \& Society, 12(3), 143-149.

Hossain Khan, M. S., \& OiriddineAbdoub, B. (2021). Flipped classroom: How higher education institutions (HEIs) of Bangladesh could move forward during COVID-19 pandemic. Social Sciences \& Humanities Open, 4(1), 100187. https:// doi.org/10.1016/j.ssaho.2021.100187

Jeong, K. O. (2017). The use of moodle to enrich flipped learning for english as a foreign language education. Journal of Theoretical and Applied Information Technology, 95(18), 4845-4852.

Lapevska, D., Velinov, A., \& Zdravev, Z. (2021). Analysis of Moodle Activities Before and After the Covid-19 Pandemic - Case Study at Goce Delchev University. Balkan Journal of applied mathematics and Informatics, 4(1). https://doi. org/10.46763/BJAMI

Martin, F., Budhrani, K., Kumar, S., \& Ritzhaupt, A. (2019). Award-winning faculty online teaching practices: Roles and competencies. Online Learning, 23(1), 184-205. https://doi.org/10.24059/olj. v23i1.1329

Murphy, M. P. A. (2020). COVID-19 and emergency eLearning: Consequences of the securitization of higher education for post-pandemic pedagogy. Contemporary Security Policy, 41(3), 492-505. https:// doi.org/10.1080/13523260.2020.1761749

Mursyidah, H., Hermoyo, R. P., \& Suwaibah, D. (2021). Does flipped learning method via MOODLE can improve outcomes and motivation of discrete mathematics learning during COVID-19 pandemic? Journal of Physics: Conference Series, 1720(1). https://doi.org/10.1088/17426596/1720/1/012007

Oguguo, B. C. E., Okeke, A. O., Dave-Ugwu, P. O., Ocheni, C. A., Ugorji, C. O., Nwoji, I. H. N., \& Ike, I. C. (2020). Assessment of ICT Skills Relevant for Effective Learning Possessed by Undergraduate Students at University of Nigeria. International Journal of Higher Education, 9(4), 206-215. https://doi.org/10.5430/ijhe. v9n4p206

Prensky, M. (2004). The Emerging Online Life of the Digital Native. The Emerging Online Life Of The Digital Native. https:// doi.org/10.4135/9781483387765.n7

Queiroga, E. M., Enríquez, C. R., Cechinel, C., Casas, A. P., Paragarino, V. R., Bencke, L. R., \& Ramos, V. F. C. (2021). Using Virtual Learning Environment Data for the Development of Institutional Educational Policies. Applied Sciences MDPI AG, 11(15), 6811. https://doi.org/10.3390/ app11156811

Rodés, V., Porta, M., Garófalo, L., \& Enríquez, C. R. (2021). Teacher Education in the Emergency: a MOOC-Inspired Teacher Professional Development Strategy Grounded in Critical Digital Pedagogy and Pedagogy of Care. Journal of Interactive Media in Education, 1(12), 1-14. https:// doi.org/10.5334/jime.657

Romero-Martín, R., Castejón-Oliva, F. J., López-Pastor, V. M., \& Fraile-Aranda, A. (2017). Formative Assessment, Communication Skills and ICT in Initial Teacher Training. Media Education Research Journal, XXV. https://doi. org/10.3916/C52-2017-07

Torres-Madroñero, E. M., TorresMadroñero, M. C., \& Ruiz Botero, L. R. (2020). Challenges and Possibilities of ICT-Mediated Assessment in Virtual Teaching and Learning Processes. Future 
Internet, 12(232), 1-20. https://doi. org $/ 10.3390 /$ fi12120232

Vilchez-Sandoval, J., Llulluy-Nunez, D., \& Lara-Herrera, J. (2021). Work in Progress: Flipped classroom as a pedagogical model in virtual education in networking courses with the Moodle Learning Management System against COVID 19. IEEE World Conference on Engineering Education (EDUNINE), 1-3. $\quad$ https://doi.org/10.1109/ EDUNINE51952.2021.9429101
Wang, T. (2009). The Transformational Promise of Information and Communications Technologies (ICTs) for the Professional Education of Architects. Educational Technology \& Society, 12(3), 206213.

Yilan, S. M., \& Koruyan, K. (2020). ICT-Based Assessment, Methods, and Programs in Tertiary Education. IGI Global. https:// doi.org/10.4018/978-1-7998-3062-7

\title{
ACADEMIC AND PROFESSIONAL PROFILE OF THE AUTHORS
}

Teresa Freire is associate investigator and professor from Departamento de Inmunobiología, Facultad de Medicina, UdelaR, Montevideo, Uruguay. She obtained a PhD in Biology, carries out experimental research in Immunology as leader of her laboratory and currently is carrying out a Master thesis in Education (Maestría en enseñanza Universitaria) in UdelaR. https://orcid.org/0000-0002-4845-4920 E-mail: tfreire@fmed.edu.uy

\section{ADDRESS}

Facultad de Medicina, UdelaR Avda. General Flores, $\mathrm{n}^{0} 2125$

Montevideo (Uruguay)

Carolina Rodríguez is associate investigator, professor and the head of Unidad de Enseñanza Virtual de Aprendizaje and Departamento de Educación, Facultad de Enfermería, UdelaR, Montevideo, Uruguay. She has a Master in Educational sciences (Maestría en enseñanza Universitaria) and currently finishing a PhD thesis in the same area, with emphasis on ICTs in higher education. https://orcid.org/oooo0002-4845-4920

E-mail: carolinacabocla@gmail.com

\author{
ADDRESS \\ Facultad de Enfermería, UdelaR \\ Jaime Cibils, $\mathrm{n}^{0} 2810$ \\ Montevideo (Uruguay)
}


T. Freire; C. RodrígueZ

The Transformation to an Online Course in Higher Education Results in Better Student Academic Performance

Date of receipt: 07/09/2021

Date of acceptance: $04 / 10 / 2021$

Date of layout: $18 / 10 / 2021$ 